\title{
Influence of H-Type and L-Type Activated Carbon in the Photodegradation of Methylene Blue and Phenol under UV and Visible Light Irradiated $\mathrm{TiO}_{2}$
}

\author{
Juan Matos*, Karina Quintana, Andreina García \\ Engineering of Materials and Nanotechnology Centre, Venezuelan Institute for Scientific \\ Research (I.V.I.C.), Caracas, Venezuela \\ Email: *jmatoslale@ivic.gob.ve
}

Received March 2, 2012; revised April 3, 2012; accepted April 13, 2012

\begin{abstract}
Photodegradation of methylene blue $(\mathrm{MB})$ and phenol $(\mathrm{Ph})$ on $\mathrm{TiO}_{2}$ in presence of $\mathrm{H}$-type and L-type activated carbons (AC) was studied. Photodegradation of $\mathrm{MB}$ and $\mathrm{Ph}$ were studied under two different lamps and results were compared against those obtained on a commercial $\mathrm{TiO}_{2}$. Apparent first order rate constant for the degradation of $\mathrm{MB}$ was higher in presence of any $\mathrm{AC}$ in comparison of $\mathrm{TiO}_{2}$ alone while only in presence of $\mathrm{AC}_{\mathrm{CO2}-800}$ phenol was photodegradated in shorter irradiation time than that required by $\mathrm{TiO}_{2}$. It can be concluded that $\mathrm{TiO}_{2}$ enhances its photoactivity by a factor up to 8.7 in the degradation of $\mathrm{MB}$ in presence of $\mathrm{AC}$ and this effect is associated to the specific surface properties of AC.
\end{abstract}

Keywords: Photocatalysis; $\mathrm{TiO}_{2}$; Activated Carbon; Methylene Blue; Phenol

\section{Introduction}

An important quantity of the total world production of azo-dyes is released in textile effluents [1]. Different technologies for the removal of dyes are adsorption, bioand chemical degradation methods including advanced oxidation technologies as heterogeneous photocatalysis. Since heterogeneous photocatalysis with $\mathrm{TiO}_{2}$ emerged as an efficient method for purifying water and air $[2,3]$ several attends such as ion doping or metal depositions have been used [4] to increase its photoefficiency. Another way to possibly increase the photoefficiency of $\mathrm{TiO}_{2}$ consists of adding an inert co-adsorbent such as activated carbon (AC) $[5,6]$. A synergy effect between both solids has been observed in the photocatalytic degradation of model pollutants [7,8]. This has been ascribed to a contact interface that promotes an appropriated diffusion of pollutants from AC to photoactive titania and introduce changes in the semiconductor properties [5-8]. Photocatalysis and adsorption with activated carbon (AC) have received an increase attention for the degradation of different dyes [9-11] and halo phenol molecules [7] where recently, we have showed that surface functionalization of AC play an important role on $\mathrm{TiO}_{2}$ photoactivity on 4-chlorophenol degradations [7]. The objective of this work is to study the photodegradation of methyl-

${ }^{*}$ Corresponding author. ene blue (MB) as a model dye and phenol (Ph) as a model aromatic molecule on UV- and visible light irradiated $\mathrm{TiO}_{2}$ in presence of $\mathrm{H}$-type and L-type $\mathrm{AC}$ which are characterized by different texture and surface functionalities.

\section{Experimental}

Methylene blue (MB) and phenol (Ph) were analytical grade and purchased from Aldrich. For comparative purpose, photocatalyst was $\mathrm{TiO}_{2} \mathrm{P} 25$ (Degussa). H-type $\mathrm{AC}$ were prepared by physical activation of a soft wood under $\mathrm{CO}_{2}$ flow at $800^{\circ} \mathrm{C}\left(\mathrm{AC}_{\mathrm{CO}_{2}-800}\right)$ or by pyrolysis under $\mathrm{N}_{2}$ flow at $1000^{\circ} \mathrm{C}\left(\mathrm{AC}_{\mathrm{N}_{2}-1000}\right)$ while L-type $\mathrm{AC}$ were prepared by impregnation with $5 \%(\mathrm{w} / \mathrm{w})$ of $\mathrm{ZnCl}_{2}$ ( $\mathrm{AC}_{\mathrm{ZnCl}_{2}-5 \%}$ ) and $\mathrm{H}_{3} \mathrm{PO}_{4}\left(\mathrm{AC}_{\mathrm{H}_{3} \mathrm{PO}_{4}-5 \%}\right)$ following activation under $\mathrm{N}_{2}$ flow at $450^{\circ} \mathrm{C}$. Samples were characterized by adsorption-desorption $\mathrm{N}_{2}$ isotherms, infrared spectroscopy (FTIR) and surface $\mathrm{pH}\left(\mathrm{pH}_{\mathrm{PZC}}\right)$. The experimental set-up [11] consists in an open to air batch photoreactor of $200 \mathrm{~mL}$ made of Pyrex. Irradiation was provided with two different lamps [11] with different UV proportions. One a $\mathrm{Hg}$ lamp $\left(82.9 \mathrm{~W} \cdot \mathrm{m}^{-2}\right.$ of $\mathrm{UV}$ and $362.6 \mathrm{~W} \cdot \mathrm{m}^{-2}$ for visible light) and metal halide (MH) lamp $\left(70.2 \mathrm{~W} \cdot \mathrm{m}^{-2}\right.$ of $\mathrm{UV}$ and $452.5 \mathrm{~W} \cdot \mathrm{m}^{-2}$ of visible) and a last one, a sodium (Na) lamp, $99 \%$ visible light $\left(8.4 \mathrm{~W} \cdot \mathrm{m}^{-2}\right.$ of $\mathrm{UV}$ and 831.6 $\mathrm{W} \cdot \mathrm{m}^{-2}$ for visible light). Photocatalytic tests were per- 
formed at $25^{\circ} \mathrm{C}$ with $62.5 \mathrm{mg} \mathrm{TiO} 2$ and $6.2 \mathrm{mg} \mathrm{AC}$ under stirring in $125 \mathrm{~mL}$ of $\mathrm{MB}, 25 \mathrm{ppm}\left(78.2 \mu \mathrm{mol} \cdot \mathrm{L}^{-1}\right)$ initial concentration or in $125 \mathrm{~mL}$ of phenol, $50 \mathrm{ppm}\left(0.5 \times 10^{-3}\right.$ $\mathrm{mol} \cdot \mathrm{L}^{-1}$ ) initial concentration. Samples were maintained in the dark by $60 \mathrm{~min}$ to complete adsorption at equilibrium before irradiation. After centrifugation of MB aliquots at some selected reaction times, samples were analyzed by UV-spectrophotometer at $664 \mathrm{~nm}$. For the case of phenol and their main intermediate products, hydroquinone (HQ) and benzoquinone (BQ), Millipore disks $(0.45 \mu \mathrm{m})$ were used to remove particulate matter before HPLC analysis. Although non-agglomerate solid particles may pass through these membranes, our experience showed that the performance of the chromatographic column was not impaired for a long period of use. The HPLC system adjusted at $270 \mathrm{~nm}$ for the detection of phenol and of the main intermediate products was used. A reverse-phase column with a mobile phase composed of acetonitrile and deionized doubly distilled water was used. The v/v ratio $\mathrm{CH}_{3} \mathrm{CN} / \mathrm{H}_{2} \mathrm{O}$ was $10 / 90$ and the flow rate was $1 \mathrm{ml} / \mathrm{min}$.

\section{Results and Discussion}

\subsection{Characterization}

Table 1 shows textural properties and $\mathrm{pH}_{\mathrm{PZC}}$ of photocatalysts. AC developed high surface areas BET $\left(\mathrm{S}_{\mathrm{BET}}\right)$ and the main pore width in the the microporous range. For the case of mixed system $\mathrm{TiO}_{2}-\mathrm{AC}, \mathrm{S}_{\mathrm{BET}}$ decreases one order magnitude with respect to activated carbon.
Table 1. BET surface area $\left(\mathrm{S}_{\mathrm{BET}}\right)$, mean pore diameter (D) and surface $\mathrm{pH}\left(\mathrm{pH}_{\mathrm{PZC}}\right)$.

\begin{tabular}{cccc}
\hline Sample & $\mathbf{S}_{\mathbf{B E T}}\left(\mathbf{m}^{2} \cdot \mathbf{g}^{-1}\right)$ & $\mathbf{D}(\AA)$ & $\mathbf{p H} \mathbf{P Z C}$ \\
\hline $\mathrm{TiO}_{2} \mathrm{P} 25$ & $45.17 \pm 0.16$ & 577.86 & 6.5 \\
$\mathrm{AC}_{\mathrm{CO}_{2}-800}$ & $942.86 \pm 1.41$ & 6.29 & 8.5 \\
$\mathrm{TiO}_{2-} \mathrm{AC}_{\mathrm{CO}_{2}-800}$ & $86.46 \pm 0.48$ & 974.01 & 6.7 \\
$\mathrm{AC}_{\mathrm{N}_{2}-1000}$ & $644.27 \pm 0.62$ & 5.90 & 8.9 \\
$\mathrm{TiO}_{2-} \mathrm{AC}_{\mathrm{N}_{2}-1000}$ & $60.40 \pm 0.39$ & 1051.78 & 6.7 \\
$\mathrm{AC}_{\mathrm{ZnCl}_{2}-5 \%}$ & $689.39 \pm 0.61$ & 5.89 & 6.0 \\
$\mathrm{TiO}_{2-} \mathrm{AC}_{\mathrm{ZnCl}_{2}-5 \%}$ & $92.51 \pm 0.50$ & 979.03 & 6.4 \\
$\mathrm{AC}_{\mathrm{H}_{3} \mathrm{PO}_{4}-5 \%}$ & $246.66 \pm 0.44$ & 5.94 & 4.0 \\
$\mathrm{TiO}_{2-\mathrm{H}_{3} \mathrm{PO}_{4}-5 \%}$ & $63.38 \pm 0.39$ & 1034.43 & 6.3 \\
\hline
\end{tabular}

This fact can be attributed to a strong interaction between both solids [12]. It can be seen from Table 1 that H-type AC presented basic $\mathrm{pH}_{\mathrm{PZC}}$ while L-type AC showed acid $\mathrm{pH}_{\mathrm{PZC}}$ which suggest the presence of basic and acid oxygenated functional groups on the surface of $\mathrm{H}$ - and L-type AC, respectively. This inference can be verified by FTIR analysis which is shown in Figure 1. It can be seen that functional surface groups principally are basic as cyclic ethers (-C-O-C-) and quinones $(\mathrm{C}=\mathrm{O})[7,13]$. For the case L-type AC, these showed acid $\mathrm{pH}_{\mathrm{PZC}}$ and by FTIR can be observed that the main functional surface group was carboxylic acid $(\mathrm{C}=\mathrm{O})$. Furthemore, cyclic ethers were also detected (-C-O-C-). Finally, it should

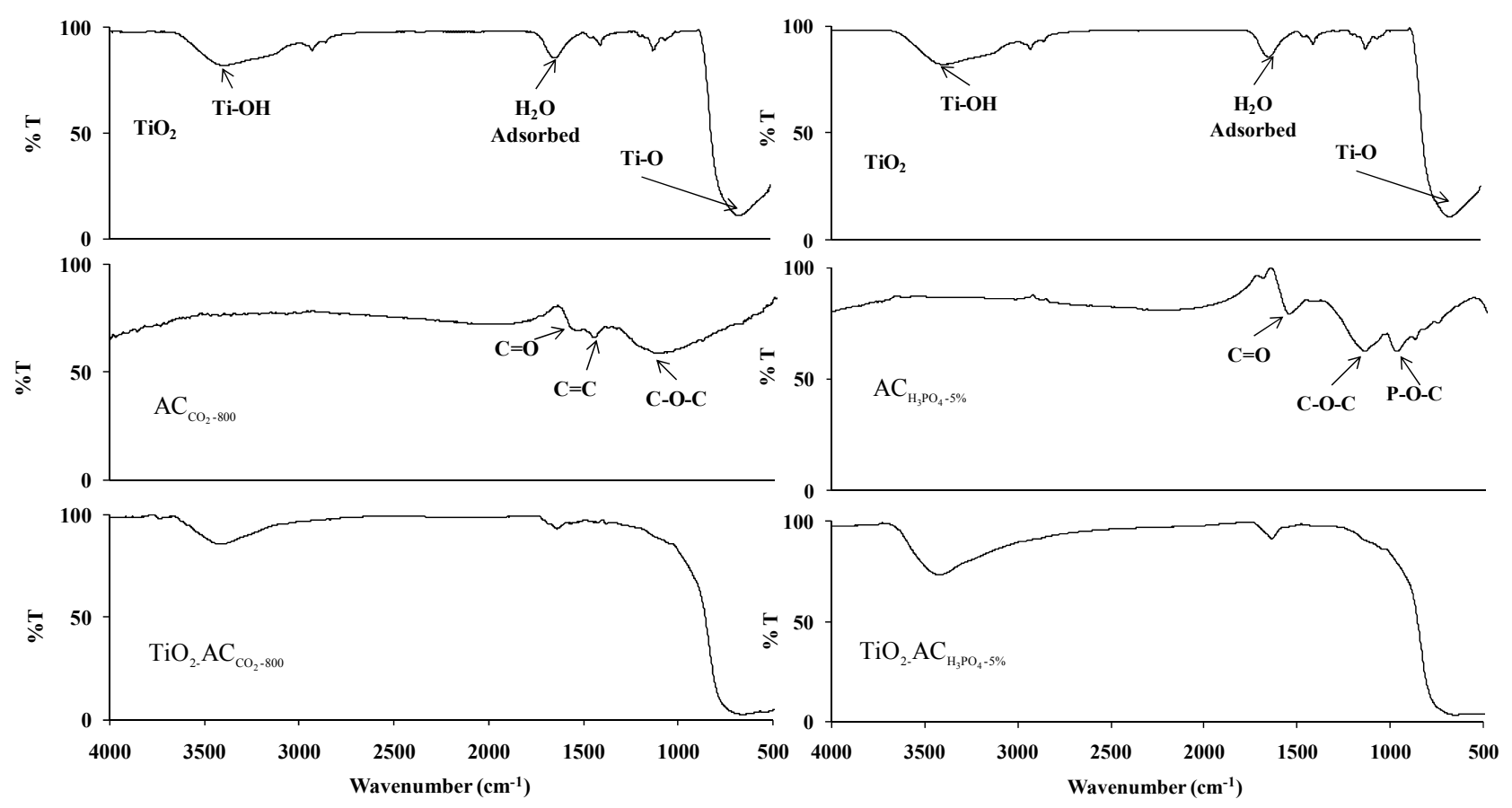

Figure 1. FTIR spectra of $\mathrm{TiO}_{2}, \quad \mathrm{AC}_{\mathrm{CO}_{2}-800}, \mathrm{AC}_{\mathrm{H}_{3} \mathrm{PO}_{4}-5 \%}, \mathrm{TiO}_{2-} \mathrm{AC}_{\mathrm{CO}_{2}-800}$, and $\mathrm{TiO}_{2-} \mathrm{AC}_{\mathrm{H}_{3} \mathrm{PO}_{4}-5 \%}$. 
be remarked the presence of phosphates in $\mathrm{AC}_{\mathrm{H}_{3} \mathrm{PO}_{4}}$ $[7,8]$. Figure 1 shows that $\mathrm{TiO}_{2}$ presented a broader peak in the region of bulk Titania in presence of AC. Also, the corresponding peaks in the AC clearly decreased in the binary materials probably by the coordination from carbon to the metallic centre in $\mathrm{TiO}_{2}$ [7]. A similar behavior in the FTIR spectra for the other AC and the binary materials was found [7]. Figure 2 shows the XRD patterns of $\mathrm{TiO}_{2}, \mathrm{AC}$ and the binary materials $\mathrm{TiO}_{2}-\mathrm{AC}$. It can be seen that no changes in the corresponding XRD patterns
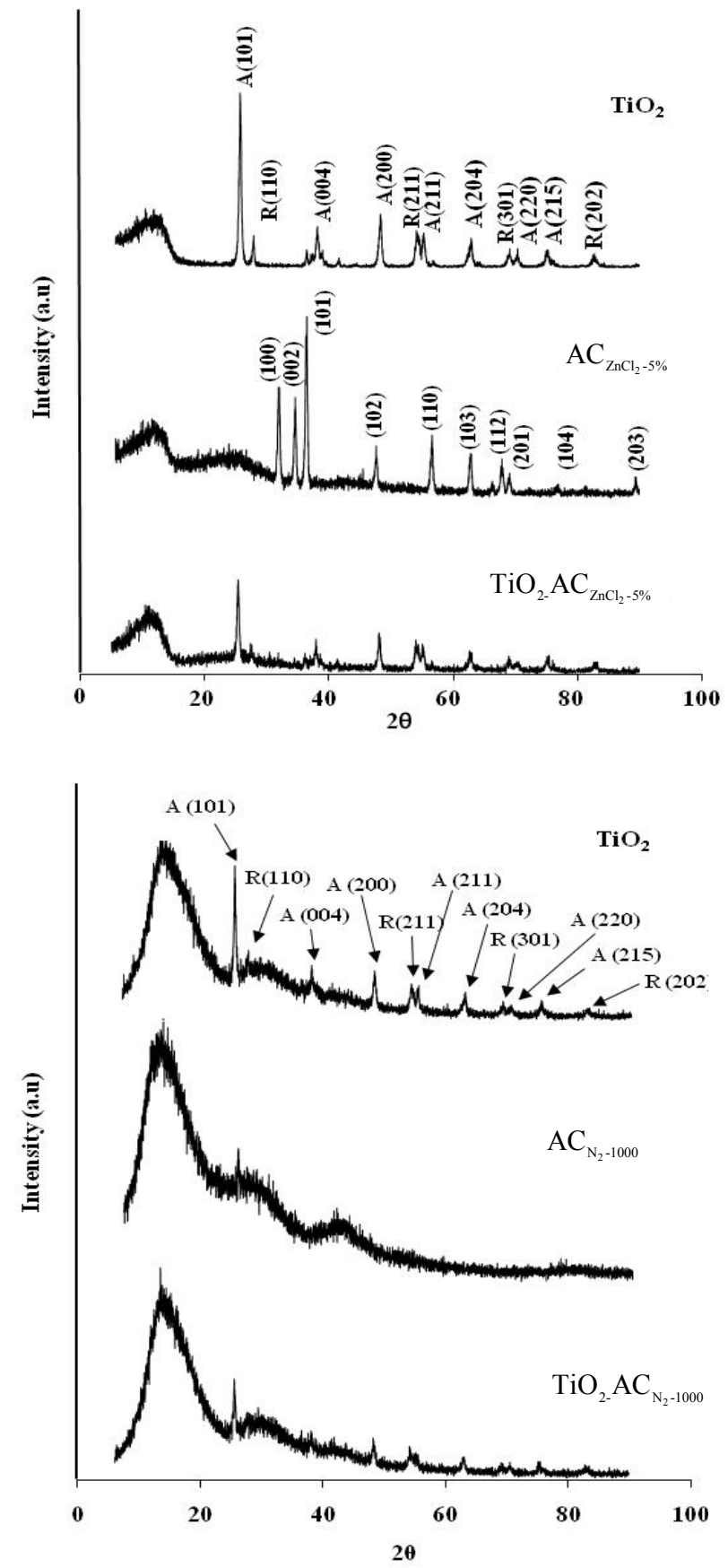

for the case of $\mathrm{TiO}_{2}-\mathrm{AC}$ in comparison than that obtained for $\mathrm{TiO}_{2}$ alone. The only change detected in the XRD pattern of the binary materials was a remarkable decrease in the main peaks attributed to a dilution effect by means of the presence of AC.

\subsection{Adsorption in the Dark of MB and Photodegradation}

Figure 3 shows the kinetics of adsorption in the dark of
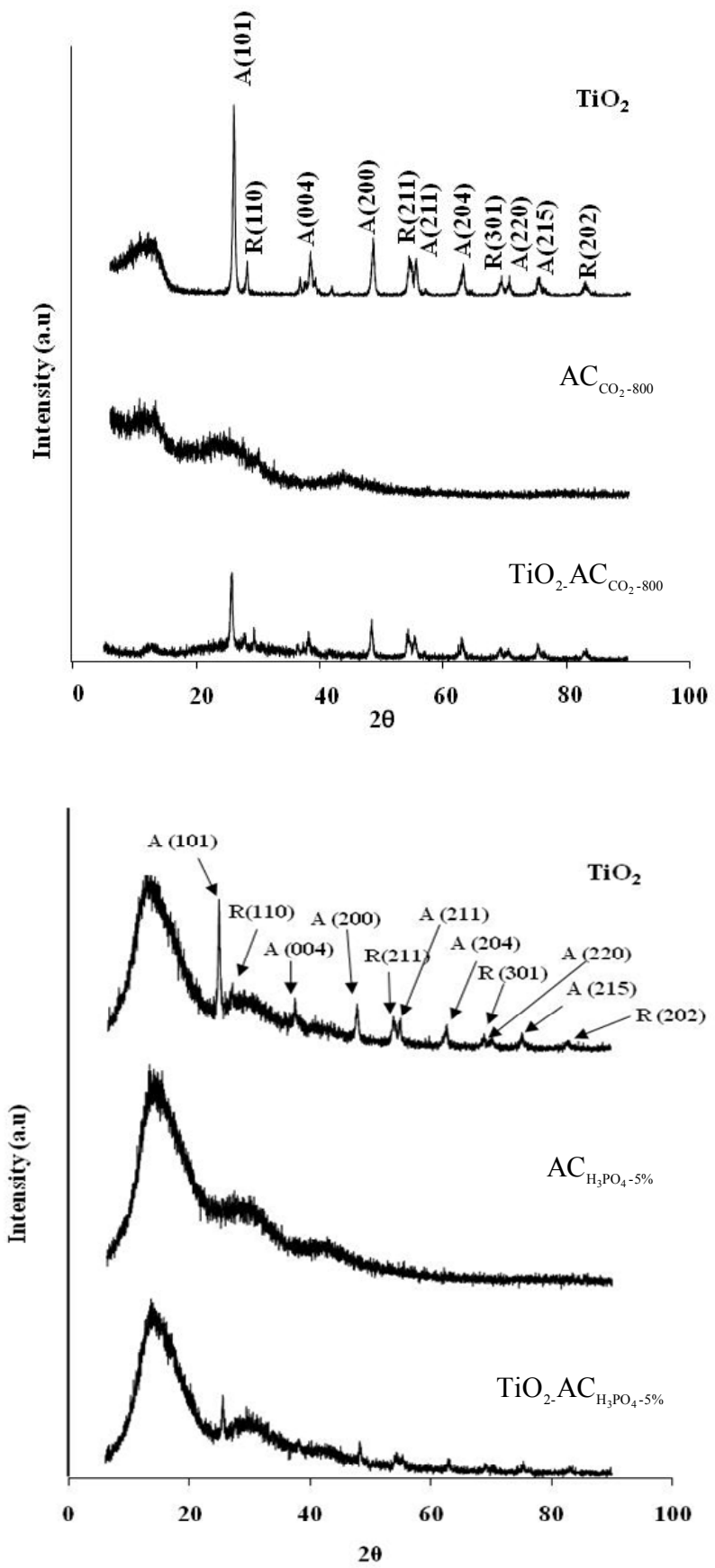

Figure 2. XRD patterns of $\mathrm{TiO}_{2}, \mathrm{AC}$ and binary materials $\mathrm{TiO}_{2}$-AC. 


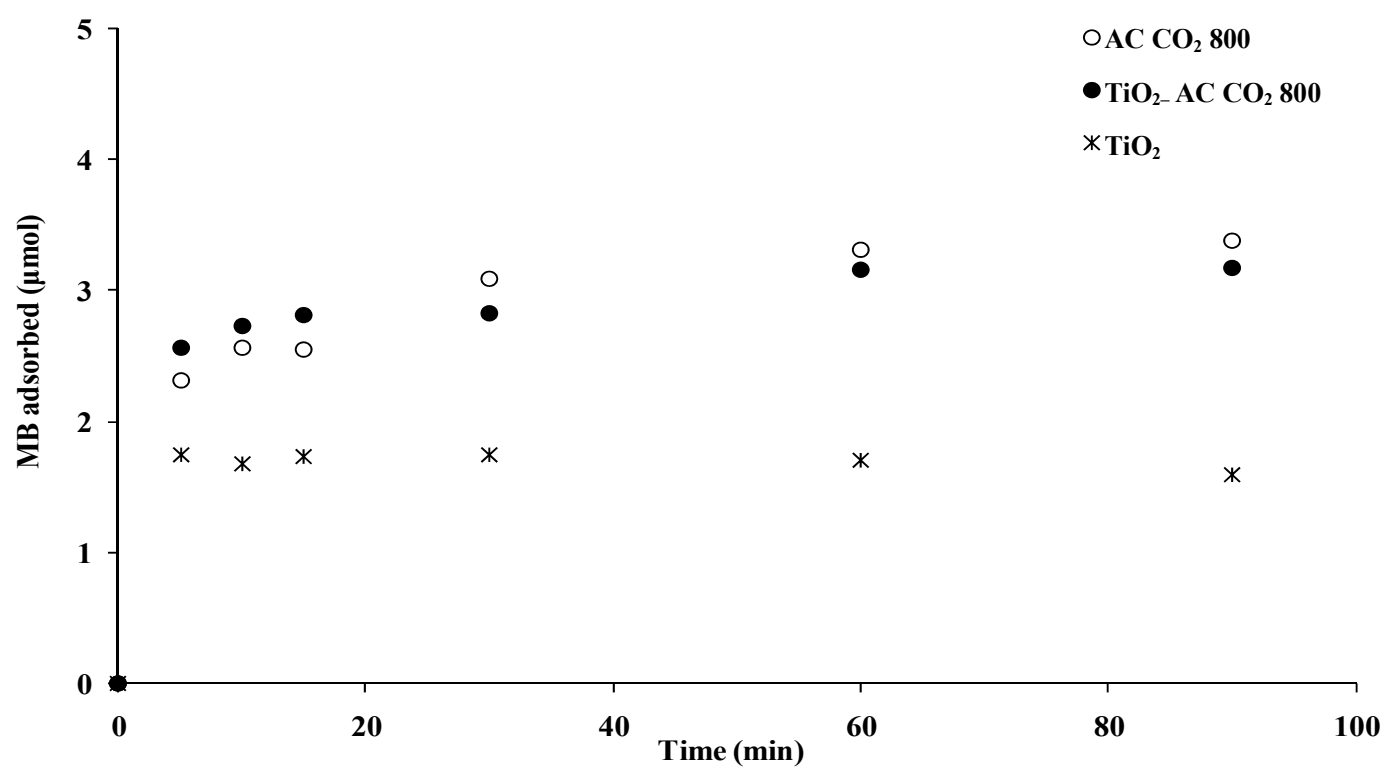

Figure 3. Micromoles adsorbed in presence of some selected solids.

$\mathrm{MB}$ on $\mathrm{AC}$ and $\mathrm{TiO}_{2}$-AC. In all cases, adsorption occurred within $30 \mathrm{~min}$ but to ensure the equilibrium of adsorption, a period of $60 \mathrm{~min}$ of adsorption in the dark was selected prior to the photodegradation experiments. The results indicated that there are no additive effects in the adsorption capacities of both solids after they are mixed. It can be ascribed to a strong interaction between $\mathrm{TiO}_{2}$ particles and AC [7]. Kinetics of photocatalytic disappearance of $\mathrm{MB}$ in presence of $\mathrm{TiO}_{2}-\mathrm{AC}$ under each lamp was performed. Figure 4 shows an example of the kinetic of $\mathrm{MB}$ photodegradation under $\mathrm{UV}$ irradiated $\mathrm{TiO}_{2}, \mathrm{TiO}_{2}-\mathrm{AC}_{\mathrm{CO}_{2}-800}$, and $\mathrm{TiO}_{2}-\mathrm{AC}_{\mathrm{N}_{2}-1000}$ samples. Assuming a first-order reaction rate [7], linear transformations (figure inset Figure 4) from the kinetic data were performed to estimate the apparent first-order rate constant $\left(\mathrm{k}_{\mathrm{app}}\right)$. Table 2 contains a summary of the kinetic results obtained for the MB photodegradation. The apparent first-order rate constant permits to estimated the photoactivity relative to $\mathrm{TiO}_{2}$ defined as

$\varphi_{\text {rel }}=\left[\mathrm{k}_{\text {app-i }} / \mathrm{k}_{\text {app-TiO }}\right]$ and the synergistic effect in the photoactivity between $\mathrm{TiO}_{2}$ and $\mathrm{AC}$ materials defined by the expression: $\mathrm{I}_{\mathrm{F}}=\left[\mathrm{k}_{\mathrm{app}-\mathrm{i}} / \mathrm{k}_{\mathrm{app}^{-\mathrm{TiO}_{2}}}+\mathrm{k}_{\mathrm{app}-\mathrm{AC}}\right]$.

It can be seen from $\mathrm{k}_{\text {app }}$ values in Table 2 that for both lamps used the binary materials $\mathrm{TiO}_{2}$-AC have higher photoactivity than that obtained on $\mathrm{TiO}_{2}$ alone and this enhancement in the photoactivity was clearly higher with the MH lamp which has higher proportion of visible light with respect to the $\mathrm{Hg}$ lamp with an enhancement in the photoactivity up to 8.7 and 6.0 times higher than $\mathrm{TiO}_{2}$ on $\mathrm{TiO}_{2}-\mathrm{AC}_{\mathrm{CO}_{2}-800}$ and $\mathrm{TiO}_{2}-\mathrm{AC}_{\mathrm{N}_{2}-1000}$. Both $\mathrm{AC}_{\mathrm{CO}_{2}-800}$ and $\mathrm{AC}_{\mathrm{N}_{2}-1000}$ can be classified as H-type [5] $\mathrm{AC}$ because its surface oxygenated functional groups are basic in nature as suggest the FTIR spectra from Figure $\mathbf{1}$ and the basic $\mathrm{pH}_{\mathrm{PZC}}$ in Table 1 . In addition, it should be pointed out that the photocatalytic activity of activated carbons is lower than that of $\mathrm{TiO}_{2}$ alone, however, a clear synergistic effect between both solids was estimated (Table 2) being clearly higher under visible light irradiation.

On the other hand, Table 2 shows that photoactivity of the binary materials $\mathrm{TiO}_{2}-\mathrm{AC}_{\mathrm{ZnCl}_{2}-5 \%}$ and $\mathrm{TiO}_{2}-\mathrm{AC}_{\mathrm{H}_{3} \mathrm{PO}_{4}-5 \%}$ were only about 3 times higher than that on $\mathrm{TiO}_{2}$ alone in any of cases of lamps studied. This fact has been attributed to a more acidic surface $\mathrm{pH}$ and to a lower surface area of these L-type AC (Table 2) [6,8]. In previous works $[5,7]$ we have showed that oxygenated functional groups in the surface of AC play a double role in photocatalytic reactions. First, these AC can play the role of electron carriers that could inhibit the recombination of photoelectrons to improve the photoactivity of $\mathrm{TiO}_{2}$ and secondly, under visible light irradiation several functional groups on carbon's surface are able to excited electrons from $\pi$ to $\pi^{*}$ orbital to then be injected into the conduction band of $\mathrm{TiO}_{2}$ [11]. This phenomena has been described by our group as a photo-assisting process $[12,14]$.

\subsection{Adsorption in the Dark of Phenol and Photodegradation}

Kinetics of adsorption in the dark of phenol on AC and $\mathrm{TiO}_{2}-\mathrm{AC}$ was performed before irradiation tests. Figure 5 shows that phenol adsorption occurred within $30 \mathrm{~min}$ but $60 \mathrm{~min}$ of adsorption in the dark was selected prior to the photodegradation experiments to ensure the equilibrium of adsorption. The results indicated that there are no additive effects in the adsorption capacities of both solids after they were mixed indicating a strong interaction 


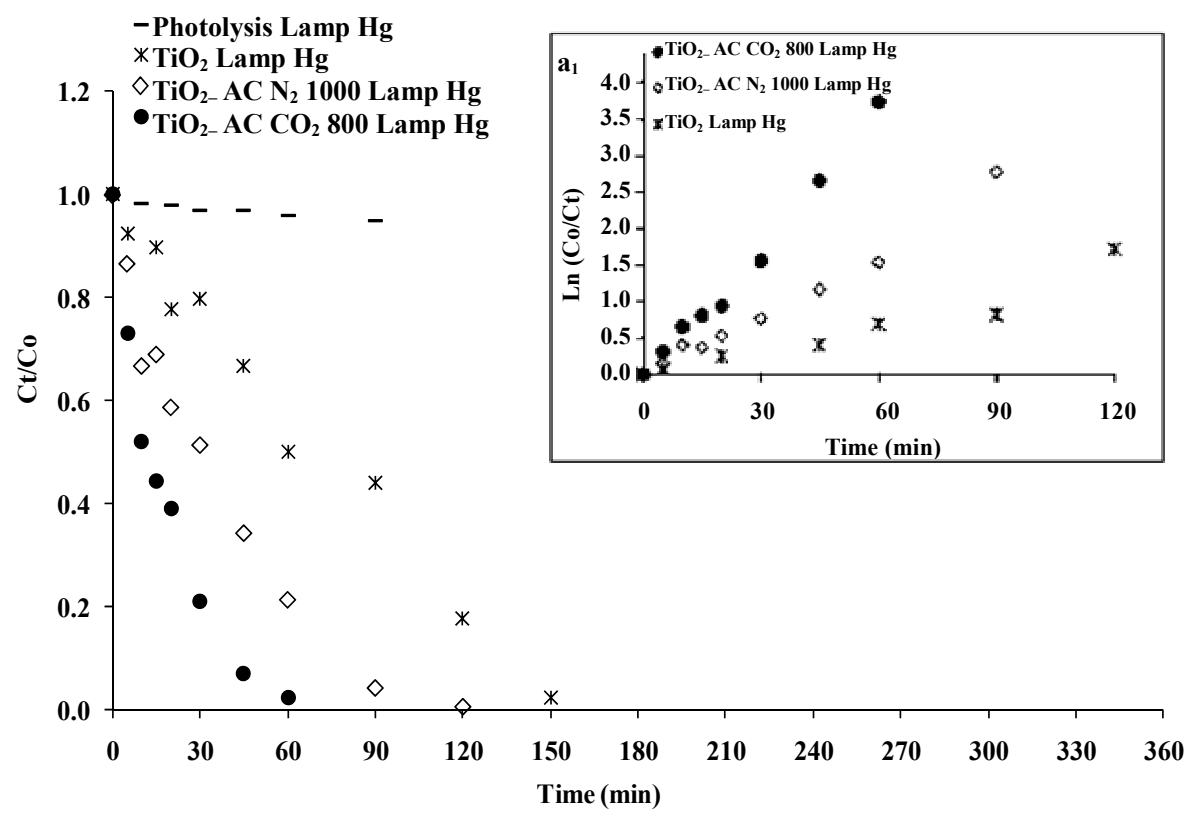

Figure 4. Kinetic of disappearance of $\mathrm{MB}$ on $\mathrm{TiO}_{2}$-AC under $\mathrm{Hg}$ Lamp (A1) and lineal regression of kinetic data (a $\left.\mathrm{a}_{1}\right)$.

Table 2. Summary of kinetics parameters obtained in the photodegradation of MB.

\begin{tabular}{|c|c|c|c|c|c|c|c|}
\hline Sample & $\operatorname{Ads}^{\mathrm{a}}(\%)$ & $\mathbf{k}_{\text {app-UV }} \times 10^{-3}\left(\min ^{-1}\right)$ & $\mathbf{I}_{\mathrm{F}-\mathrm{UV}}{ }^{\mathbf{b}}$ & $\varphi_{\text {rel-UV }}{ }^{\mathrm{c}}$ & $\mathbf{k}_{\text {app-Vis }} \times 10^{-3}\left(\min ^{-1}\right)$ & $\mathbf{I}_{\mathrm{F}-\mathrm{V} \text { is }}{ }^{\mathbf{b}}$ & $\varphi_{\text {rel-Vis }}{ }^{\mathrm{c}}$ \\
\hline $\mathrm{TiO}_{2} \mathrm{P} 25$ & 25 & 12.10 & 1.0 & 1.0 & 4.60 & 1.0 & 1.0 \\
\hline $\mathrm{AC}_{\mathrm{CO}_{2}-800}$ & 33 & 4.04 & - & 0.3 & 2.59 & - & 0.6 \\
\hline $\mathrm{TiO}_{2-} \mathrm{AC}_{\mathrm{CO}_{2}-800}$ & 31 & 59.12 & 3.7 & 4.9 & 39.89 & 5.5 & 8.7 \\
\hline $\mathrm{AC}_{\mathrm{N}_{2}-1000}$ & 23 & 3.33 & - & 0.3 & 2.24 & - & 0.5 \\
\hline $\mathrm{TiO}_{2-} \mathrm{AC}_{\mathrm{N}_{2}-1000}$ & 28 & 34.48 & 2.2 & 2.8 & 27.80 & 4.1 & 6.0 \\
\hline $\mathrm{AC}_{\mathrm{ZnCl}-5 \%}$ & 27 & 1.10 & - & 0.1 & 2.54 & - & 0.6 \\
\hline $\mathrm{TiO}_{2-} \mathrm{AC}_{\mathrm{ZnCl}_{2}-5 \%}$ & 26 & 28.85 & 2.2 & 2.4 & 14.63 & 2.0 & 3.2 \\
\hline $\mathrm{AC}_{\mathrm{H}_{3} \mathrm{PO}_{\mathrm{C}^{-}-5 \%}}$ & 14 & 0.71 & - & 0.1 & 1.01 & - & 0.2 \\
\hline $\mathrm{TiO}_{2-\mathrm{H}_{3} \mathrm{PO}_{4_{4}-5 \%}}$ & 23 & 39.41 & 3.1 & 3.3 & 13.39 & 2.4 & 2.9 \\
\hline
\end{tabular}

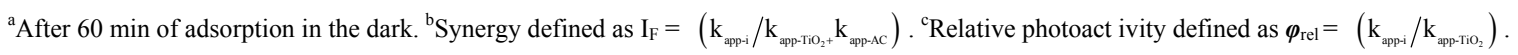

between $\mathrm{TiO}_{2}$ and $\mathrm{AC}[6,7]$.

Figure 6(a) shows the kinetics of disappearance of phenol in absence of solids (direct photolysis) and under some selected solids irradiated with UV light (Hg lamp). Linear transformations from the kinetic data were performed assuming a first-order reaction rate (Figure 6(b)). Apparent rate constant of first-order $\left(\mathrm{k}_{\text {app }}\right)$ and photocatalytic activity relative to $\mathrm{TiO}_{2}$ alone $\left(\mathrm{A}_{\text {photo }}\right)$ defined as $\mathrm{k}_{\text {app-i }} / \mathrm{k}_{\text {app-TiO }}$, were estimated. These values are compiled in Table 3. It can be seen in Figure 6 that disappearance of phenol by direct photolysis without solids and under irradiated AC were negligible. Table 3 shows that $\mathrm{k}_{\text {app }}$ was higher under the Hg Lamp with respect to MH Lamp, for all systems studied. $\mathrm{TiO}_{2}-\mathrm{AC}_{\mathrm{CO}_{2}-800}$ presented higher photoactivity that $\mathrm{TiO}_{2}$ alone. The other binary materials
$\mathrm{TiO}_{2}$-AC showed moderate photoactivity under $\mathrm{Hg}$ lamp and inhibition of the photoactivity under MH lamp. The enhancement in the photoactivity of $\mathrm{TiO}_{2}$ can be due to the presence of a common contact interface between both solids as reported elsewhere for the case of 4-chlorophenol [7,8].

In spite of phenol adsorbed in the dark (Table 3) on $\mathrm{TiO}_{2}-\mathrm{AC}_{\mathrm{N}_{2}}$ is lightly higher than that adsorbed on $\mathrm{TiO}_{2}-\mathrm{AC}_{\mathrm{CO}_{2}}$, it can be seen from Figure 6(a) that photocatalytic activity of the $\mathrm{TiO}_{2}-\mathrm{AC}_{\mathrm{CO}_{2}}$ binary material is higher than that of $\mathrm{TiO}_{2}-\mathrm{AC}_{\mathrm{N}_{2}}$. This behavior can be attributed to two main reasons. First, $\mathrm{TiO}_{2}-\mathrm{AC}_{\mathrm{N}_{2}}$ has a lower BET surface area than that of $\mathrm{TiO}_{2}-\mathrm{AC}_{\mathrm{CO}_{2}}$ (Table 1) with a concomitant less capability to adsorb both phenol as the main intermediate products. In addition, 


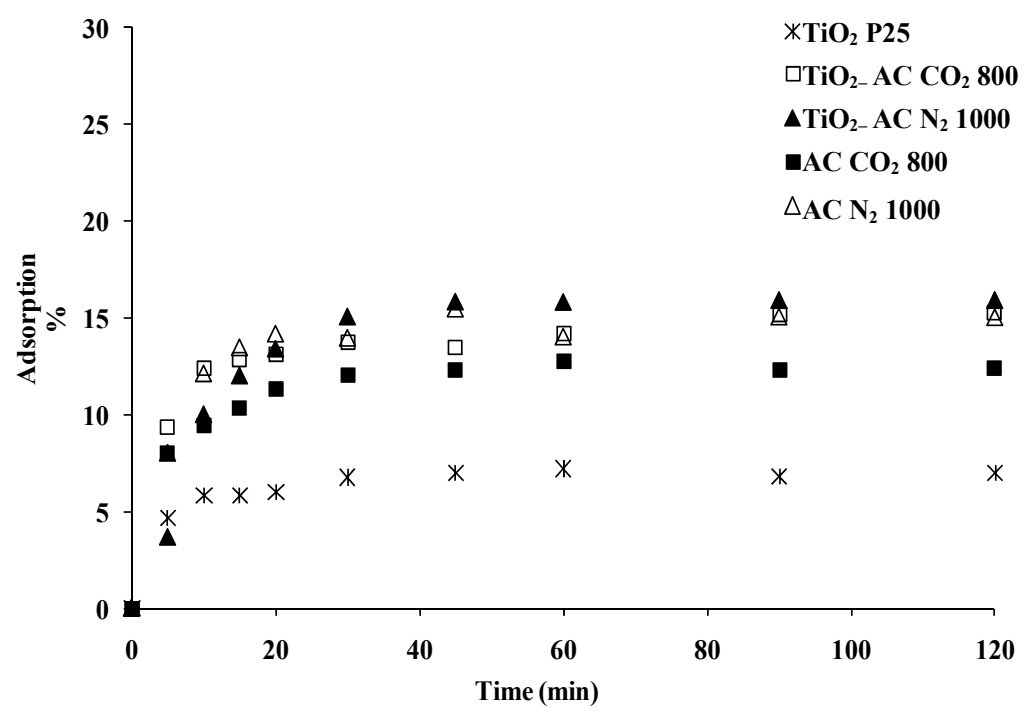

Figure 5. Phenol adsorbed in the dark on some selected solids.

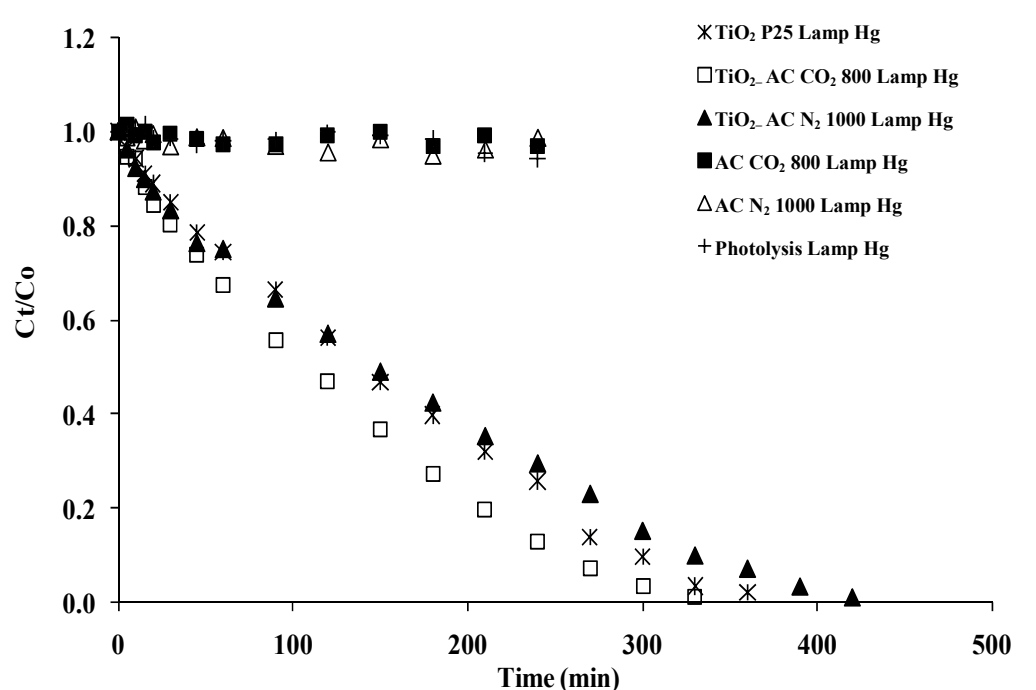

(a)

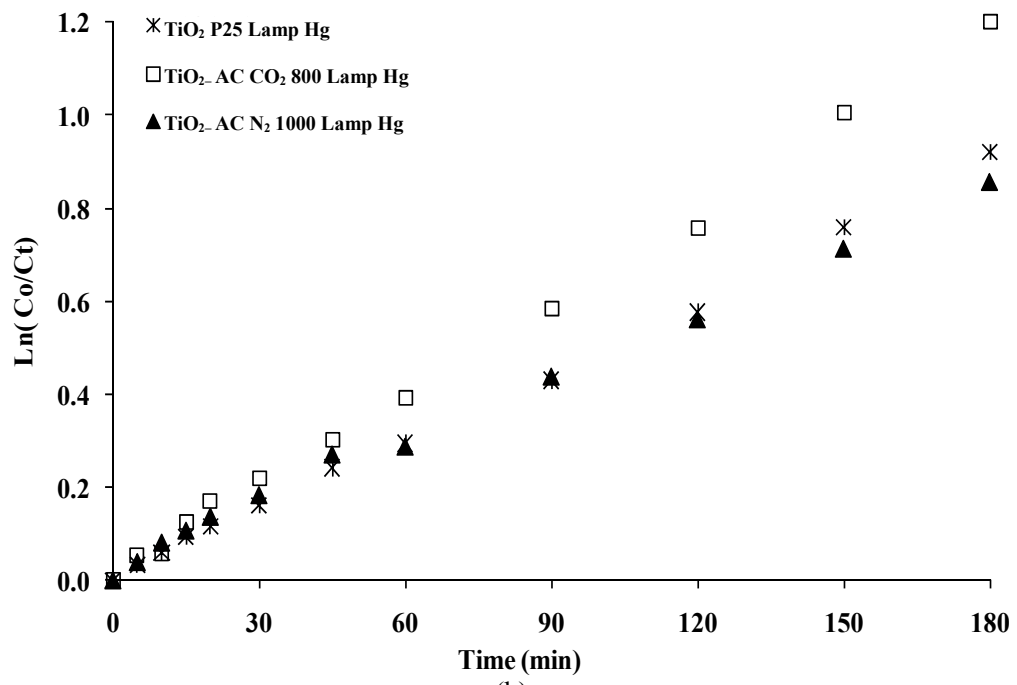

(b)

Figure 6. (a) Kinetic of disappearance of phenol on $\mathrm{TiO}_{2}-\mathrm{AC}$ under $\mathrm{Hg}$ Lamp; (b) Lineal regression of the kinetic data. 
Table 3. Kinetic parameters in the degradation of phenol.

\begin{tabular}{|c|c|c|c|c|c|c|c|}
\hline \multirow[b]{2}{*}{ Sample } & \multirow[b]{2}{*}{ Ads $\%$} & \multicolumn{3}{|c|}{ UV irradiation (Hg lamp) } & \multicolumn{3}{|c|}{ Visible irradiation (MH lamp) } \\
\hline & & $\mathrm{k}_{\mathrm{app}} \times 10^{-3}\left(\mathrm{~min}^{-1}\right)$ & $\mathrm{R}^{2 \mathrm{a}}$ & $\mathrm{A}_{\text {photo }}{ }^{\mathrm{b}}$ & $\mathrm{k}_{\mathrm{app}} \times 10^{-3}\left(\mathrm{~min}^{-1}\right)$ & $\mathrm{R}^{2 \mathrm{a}}$ & $\mathrm{A}_{\text {photo }}{ }^{\mathrm{b}}$ \\
\hline $\mathrm{TiO}_{2}$ & 6.8 & 5.02 & 0.9973 & 1.00 & 4.41 & 0.9980 & 1.00 \\
\hline $\mathrm{TiO}_{2-}-\mathrm{AC}_{\mathrm{CO}_{2}-800}$ & 14.8 & 6.83 & 0.9936 & 1.4 & 5.02 & 0.9866 & 1.2 \\
\hline $\mathrm{TiO}_{2-} \mathrm{AC}_{\mathrm{ZnCl}_{2}-5 \%}$ & 13.1 & 5.22 & 0.9878 & 1.1 & 3.45 & 0.9826 & 0.8 \\
\hline $\mathrm{TiO}_{2-} \mathrm{AC}_{\mathrm{N}_{2}-1000}$ & 15.8 & 4.82 & 0.9894 & 1.0 & 3.16 & 0.9764 & 0.7 \\
\hline $\mathrm{TiO}_{2-} \mathrm{AC}_{\mathrm{H}_{3} \mathrm{PO}_{4}-5 \%}$ & 10.3 & 5.53 & 0.9883 & 1.1 & 4.14 & 0.9782 & 0.9 \\
\hline
\end{tabular}

${ }^{\mathrm{a}} \mathrm{R}$ is the square factor of the lineal regression. ${ }^{\mathrm{b}} \mathrm{Photocatalytic} \mathrm{activity} \mathrm{relative} \mathrm{to} \mathrm{TiO}_{2}$ defined as $\mathbf{A}_{\text {photo }}=\left(\mathrm{k}_{\text {app-i }} / \mathrm{k}_{\text {app-TiO }}\right)$.

our group has been previously reported for the case of the 4-chlorophenol photodegradation [5,7] that $\mathrm{AC}_{\mathrm{CO}_{2}}$ has a more intimated interaction than $\mathrm{AC}_{\mathrm{N}_{2}}$ with the Ti atoms in $\mathrm{TiO}_{2}$. We have shown that this interaction occurs by means of a common contact interface [7] spontaneously created during reaction between both solids by the coordination the oxygenated functional groups on $\mathrm{AC}_{\mathrm{CO}_{2}}$, mainly cyclic ethers and carboxylate anions (Figure 1). This interaction is clearly lower for the case of $\mathrm{TiO}_{2}$ and $\mathrm{AC}_{\mathrm{N}_{2}}$ than with $\mathrm{AC}_{\mathrm{CO}_{2}}$ because $\mathrm{AC}_{\mathrm{N}_{2}}$ has lower oxygen surface composition than that of $\mathrm{AC}_{\mathrm{CO}_{2}}$, about $7 \%$ against $12 \mathrm{wt} \%$, respectively [5].

Figure 7 shows the kinetic of hydroquinone (HQ) and benzoquinone (BQ) appearance and disappearance during phenol photodegradation under UV-irradiated some selected solids. These two molecules were the main intermediates products observed in all samples studied and under both types of irradiation. The maximum time of appearance and time require for the total disappearance of intermediates are lower for the binary materials $\mathrm{TiO}_{2}-\mathrm{AC}$ with respect to $\mathrm{TiO}_{2}$ alone, only in presence of mixed system that showed higher photocatalytic activity. This fact is an indicative that intermediates products are also photodegradated in shorter irradiation time than that on $\mathrm{TiO}_{2}$ reported by our group for the case of 4-chlorophenol [7,8]. As we appointed above, an explanation for the apparent synergy effect can be based on the conventional Langmuir-Hinshelnwood mechanism with the rate being proportional to the surface coverage $\theta$ varying as:

$$
\mathrm{r}=\mathrm{k} \theta=\mathrm{k}\left[\mathrm{K}_{\mathrm{ads}} \cdot \mathrm{C}_{\mathrm{eq}} /\left(1+\mathrm{K}_{\mathrm{ads}} \cdot \mathrm{C}_{\mathrm{eq}}+\Sigma \mathrm{KiCi}\right)\right] .
$$

being: $\mathrm{K}_{\mathrm{ads}}$ and $\mathrm{K}_{\mathrm{i}}$ correspond to the adsorption constants of phenol and the intermediate $\mathrm{i}, \mathrm{C}_{\mathrm{eq}}$ and $\mathrm{C}_{\mathrm{i}}$ is the phenol and intermediate concentration in solution after achieve the equilibrium adsorption in the dark. Owing to the similarity of the reactants and of the main initial aromatic intermediates formed, the term $\Sigma \mathrm{Ki} \cdot \mathrm{Ci}$ can be estimated as constant, thus explaining the apparent first order:

$$
\mathrm{r} \approx \mathrm{k}\left[\mathrm{K}_{\mathrm{ads}} \cdot \mathrm{C}_{\mathrm{eq}} /(1+\Sigma \mathrm{KiCi})\right]=\mathrm{K}_{\mathrm{ads}} \cdot \mathrm{C}_{\mathrm{eq}}
$$

The nature of the intermediate main products (HQ and $\mathrm{BQ}$ ) is the same for $\mathrm{TiO}_{2}-\mathrm{AC}$ as for neat $\mathrm{TiO}_{2}$. This confirms that reaction mechanism has not been altered nor changed by the addition of AC, or at least, for these carbons [15]. UV photons create electron hole pairs in Titania

$$
\mathrm{TiO}_{2}+\mathrm{hv} \rightarrow e^{-}+p^{+}
$$

which separate because of electron transfer reactions:

$$
\begin{aligned}
& \mathrm{O}_{2}+e^{-} \rightarrow \mathrm{O}_{2}-(\text { ads }) \\
& \mathrm{O}_{2}+p^{+} \rightarrow \mathrm{OH}^{\circ} .
\end{aligned}
$$

As we have already appointed in previous works [15] $\mathrm{OH}^{\circ}$ radicals created by Equation (5) react with phenolic compounds to produce hydroxylated aromatic compounds, mainly hydroquinone in equilibrium with benzoquinone (Figure 7), and then aliphatic fragments resulting from the opening before producing $\mathrm{CO}_{2}$ such as picric acid, oxalic acids, and humic acids, are difficult to well quantified by HPLC. Thus, synergy effect can also be pointed out in the kinetics of intermediate products appearance and disappearance. For hydroquinone, its kinetics can be summarized as:

$$
\begin{gathered}
k 1 \quad k 2 \quad k 3 \quad k n \\
\mathrm{C}_{6} \mathrm{H}_{5}-\mathrm{OH} \rightarrow \mathrm{HQ} \rightarrow \mathrm{BQ} \rightarrow \cdots \rightarrow \mathrm{CO}_{2}
\end{gathered}
$$

\section{Conclusions}

For the case of MB photodegradation, the binary materials $\mathrm{TiO}_{2}$-AC showed a clear increase in the photocatalytic activity with respect to $\mathrm{TiO}_{2}$ alone, under the two lamps studied. Under the $\mathrm{MH}$ lamp which has a higher proportion of visible light, $\mathrm{TiO}_{2}$ in presence of H-type $\mathrm{AC}$ showed higher photocatalytic activity with respect to $\mathrm{TiO}_{2}$ in presence of L-type AC. This beneficial effect has been attributed to the specific properties of H-type AC with a high surface area and basic $\mathrm{pH}_{\mathrm{PZC}}$. By contrast, for the case of phenol photodegradation, only $\mathrm{TiO}_{2}-\mathrm{AC}_{\mathrm{CO}_{2}-800}$ 

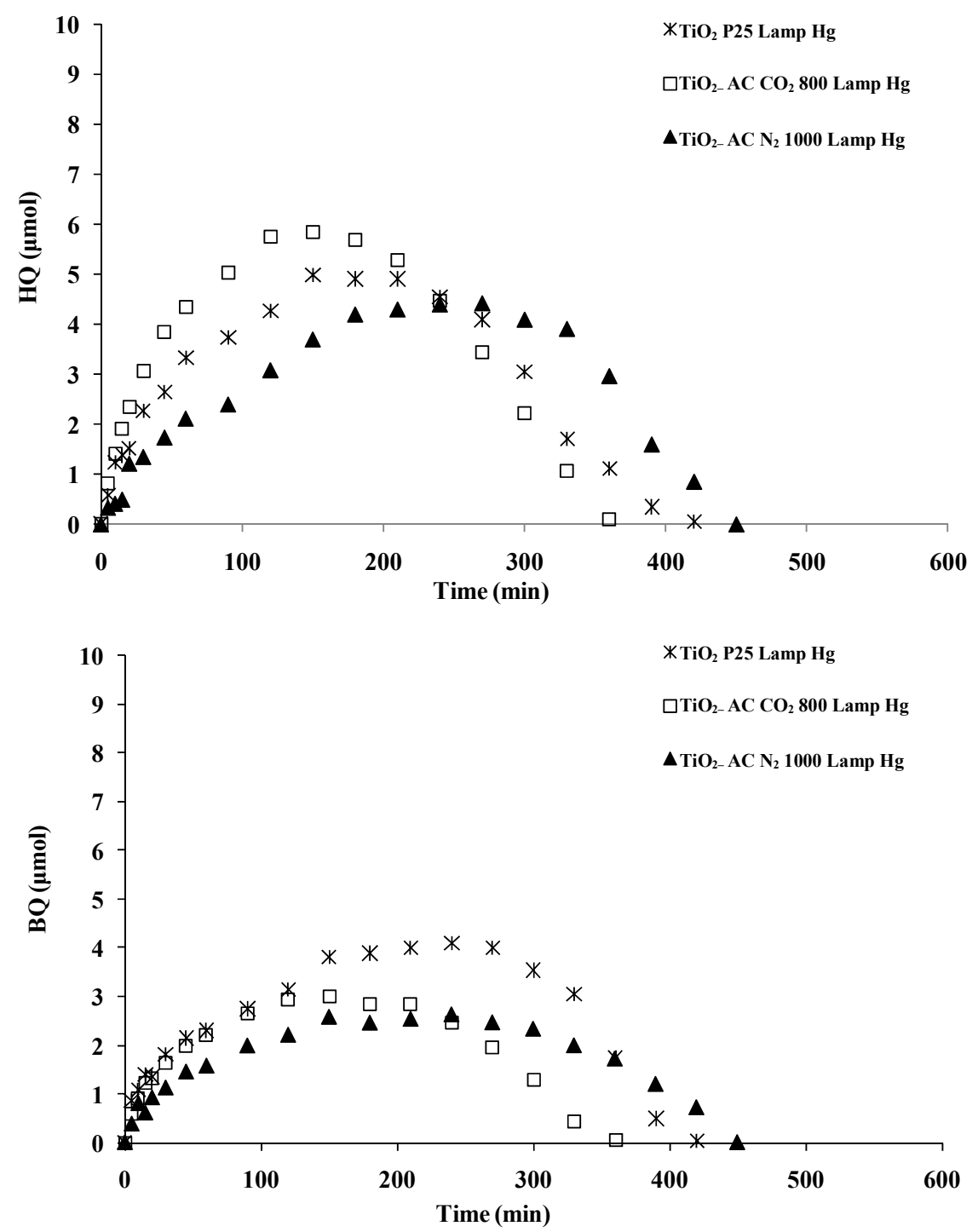

Figure 7. Hydroquinone (HQ) and benzoquinone (BQ) appearance and disappearance during phenol photodegradation with some selected solids under Hg Lamp.

presented higher photocatalytic activity than $\mathrm{TiO}_{2}$.

\section{REFERENCES}

[1] A. Houas, H. Lachheb, M. Ksibi, E. Elaloui, C. Guillard and J. M. Herrmann, "Photocatalytic Degradation Pathway of Methylene Blue in Water," Applied Catalysis B: Environmental, Vol. 31, No. 2, 2001, pp. 145-157. doi:10.1016/S0926-3373(00)00276-9

[2] J. M. Herrmann, C. Guillard and P. Pichat, "Heterogeneous Photocatalysis: An Emerging Technology for Water Treatment," Catalysis Today, Vol. 17, No. 1-2, 1993, pp. 7-20. doi:10.1016/0920-5861(93)80003-J

[3] O. Legrini and E. Oliveros, "Photochemical Processes for Water Treatment," Chemical Reviews, Vol. 93, No. 2, 1993, pp. 671-698. doi:10.1021/cr00018a003
[4] J. M. Herrmann, J. Didier and P. Pichat, "Effect of Chromium Doping on the Electrical and Catalytic Properties of Powder Titania under UV and Visible Illumination," Chemical Physics Letters, Vol. 108, No. 6, 1984, pp. 618622. doi:10.1016/0009-2614(84)85067-8

[5] T. Cordero, J. M. Chovelon, C. Duchamp, C. Ferronato and J. Matos, "Surface Nano-Aggregation and Photocatalytic Activity of $\mathrm{TiO}_{2}$ on H-Type Activated Carbons," Applied Catalysis B: Environmental, Vol. 73, No. 3-4, 2007, pp. 227-235. doi:10.1016/j.apcatb.2006.10.012

[6] T. Cordero, C. Duchamp, J. M. Chovelon, C. Ferronato and J. Matos, "Influence of L-Type Activated Carbons on Photocatalytic Activity of $\mathrm{TiO}_{2}$ in 4-Chlorophenol Photodegradation," Journal of Photochemistry and Photobiology A: Chemistry, Vol. 191, No. 2-3, 2007, pp. 122-131. doi:10.1016/j.jphotochem.2007.04.012

[7] J. Matos, A. García and P. S. Poon, "Environmental 
Green Chemistry Applications of Nanoporous Carbons," Journal of Materials Science, Vol. 45, No. 18, 2010, pp. 4934-4944. doi:10.1007/s10853-009-4184-2

[8] J. Matos, A. García, T. Cordero, J. M. Chovelon and C. Ferronato, "Eco-Friendly $\mathrm{TiO}_{2}$-AC Photocatalyst for the Selective Photooxidation of 4-Chlorophenol," Catalysis Letter, Vol. 130, No. 3-4, 2009, pp. 568-574. doi:10.1007/s10562-009-9989-8

[9] W. Wang, C. Gomes and J. L. Faria, "Photocatalytic Degradation of Chromotrope 2R Using Nanocrystalline $\mathrm{TiO}_{2}$ /Activated-Carbon Composite Catalysts," Applied Catalysis B: Enviromental, Vol. 70, No. 1-4, 2007, pp. 470-478.

[10] J. M. Peralta-Hernández, J. Manríquez, Y. Meas-Vong, F. J. Rodríguez, T. W. Chapman, M. I. Maldonado and L. A. Godínez, "Photocatalytic Properties of Nano-Structured $\mathrm{TiO}_{2}$-Carbon Films Obtained by Means of Electrophoretic Deposition," Journal of Hazardous Materials, Vol. 147, No. 1-2, 2007, pp. 588-593. doi:10.1016/j.jhazmat.2007.01.053

[11] J. Matos, A. Garcia, L. Zhao and M. M. Titirici, "Solvothermal Carbon-Doped $\mathrm{TiO}_{2}$ Photocatalyst for the Enhanced Methylene Blue Degradation under Visible Light," Applied Catalysis A: General, Vol. 390, No. 1-2, 2010, pp. 175-182. doi:10.1016/j.apcata.2010.10.009
[12] J. Matos, E. García-López, L. Palmisano, A. García and G. Marci, "Influence of Activated Carbon in $\mathrm{TiO}_{2}$ and $\mathrm{ZnO}$ Mediated Photo-Assisted Degradation of 2-Propanol in Gas-Solid Regime," Applied Catalysis B: Environmental, Vol. 99, No. 1-2, 2010, pp. 170-180. doi:10.1016/j.apcatb.2010.06.014

[13] A. P. Terzyk, "The Influence of Activated Carbon Surface Chemical Composition on the Adsorption of Acetaminophen (Paracetamol) in Vitro: Part II. TG, FTIR, and XPS Analysis of Carbons and the Temperature Dependence of Adsorption Kinetics at the Neutral pH," Colloids and Surfaces A: Physicochemical and Engineering Aspects, Vol. 177, No. 1, 2001, pp. 23-45. doi:10.1016/S0927-7757(00)00594-X

[14] J. Matos, T. Marino, R. Molinari and H. García, "Hydrogen Photoproduction under Visible Irradiation of Au$\mathrm{TiO}_{2} /$ Activated Carbon," Applied Catalysis A: General, Vol. 417-418, 2012, pp. 263-272. doi:10.1016/j.apcata.2011.12.047

[15] J. Matos, J. Laine, J. M. Herrmann, D. Uzcategui and J. L. Brito, "Influence of Activated Carbon upon Titania on Aqueous Photocatalytic Consecutive Runs of Phenol Photodegradation," Applied Catalysis B: Environmental, Vol. 70, 2007, pp. 461-469. doi:10.1016/j.apcatb.2005.10.040 